\title{
Breaking and re-entering: British American Tobacco in China 1979-2000
}

\author{
K Lee, A B Gilmore, J Collin
}

Tobacco Control 2004;13(Suppl II):ii88-ii95. doi: 10.1136/tc.2004.009258

See end of article for authors' affiliations

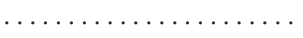

Correspondence to: Dr Kelley Lee, Centre on Global Change and Health, London School of Hygiene \& Tropical Medicine, Keppel Street, London UK WC1E 7HT; kelley.lee@|shtm.ac.uk
Objectives: To analyse the strategy used by British American Tobacco (BAT) to re-enter the Chinese market from 1979 to 2000 after historically dominating the market before the 1950s.

Design: Analysis of tobacco industry document files to date available only on-site at the Guildford Depository operated by BAT. An additional search of recent documents related to BAT, placed in the Minnesota Depository, was also carried out.

Results: BAT has been committed to regaining its historically dominant position in China since the country reopened to foreign companies in 1979. Initially, BAT remained cautious relative to competitors in seeking joint ventures, finding market access hindered by bureaucratic complexity, restrictions on foreign investment and imports quotas, and later an advertising ban. Instead, the documents suggest BAT strongly relied on illegal imports to expand market presence of State Express 555 and other key brands. It was only when risks to contraband sales increased that the company made greater efforts to establish a legal presence in the country. Attempts to stress the long history of BAT in China and a proclaimed commitment to corporate social responsibility have been used to facilitate later negotiations.

Conclusion: China has remained relatively closed to transnational tobacco companies (TTCs) during its transition to a market economy, maintaining a firm grip over foreign investment and imports. Nonetheless, BAT has circumvented such restrictions through illegal imports and exploitation of inconsistencies in the local enforcement of advertising bans. Governments need to understand and address the full range of market entry tactics by TTCs in order to ensure effective tobacco control.
C hina has been the ultimate prize for tobacco companies since the industry set its sights on international markets over a century ago. James B Duke, first chairman of British American Tobacco (BAT), famously asked that a globe be brought to him and pointed to China as the key market where he wanted to sell. ${ }^{1}$ With a population today of 1.2 billion, with over 350 million smokers, China is much the world's largest cigarette market, accounting for one in three cigarettes smoked in the world ( 1.7 trillion sticks in 2000). ${ }^{3}$ Critically for the expansion of transnational tobacco companies (TTCs), China remains a growing market. From the early 1970s to early 1990s, per capita consumption of cigarettes rose by $260 \%,{ }^{4}$ with further rapid growth during 2001-2002 when sales volume rose by $5.5 \%$, and commercial profits and taxes by $19.6 \%$.

During the first half of the 20th century, BAT dominated the lucrative Chinese market, becoming the company's key overseas operation. Exporting its first cigarette to China in 1890, the market grew meteorically from 1.25 billion sticks in 1902 to 55 billion sticks in $1937 .{ }^{6}$ By as early as 1924 BAT had established an $82 \%$ market share. ${ }^{7}$ Throughout the 1920s, BAT exports to China from its US base exceeded those for all other countries combined. ${ }^{8}$ Political and economic instability meant that the country never provided a straightforward business climate, but the market's closure in the early 1950s, after the establishment of the People's Republic of China, lost BAT its largest source of foreign earnings ${ }^{9}$ and BAT has long sought to re-establish its presence.

The announcement of China's "open door policy" in the late 1970s signalled that the country was ready to do business again, and offered TTCs a timely opportunity as traditional markets began to decline. Although the Chinese tobacco industry remained strictly controlled by a state owned monopoly, TTCs saw China as the ultimate prize. As one
Rothman's official stated, "Thinking about Chinese smoking statistics is like trying to think about the limits of space."10

This paper uses corporate documents from BAT to describe its strategy to re-enter China from 1979 to 2000, complementing an earlier analysis of on-line industry documents. ${ }^{11}$ While this previous work primarily describes market entry tactics by Philip Morris and other companies, this paper reveals the initial strategies deployed by BAT. It examines the company's relations with the Chinese government, and highlights how BAT countered restrictions in market access through strategic exploitation and oversight of contraband markets. While seeking to apply strategies used in other emerging markets, notably the "staged approach" to market entry, ${ }^{12}{ }^{13}$ the company found itself needing to adapt to the "difficult market" it encountered. An understanding of the strategies used will contribute to strengthening regulation of the industry's expansion in the developing world.

\footnotetext{
Abbreviations: BAT, British American Tobacco; BATUKE, British American Tobacco United Kingdom Export; BCF, Beijing Cigarette Factory; BLI, Beijing Light Industry No. 1 Bureau; CORA, Consumer and Regulatory Affairs; CSR, corporate social responsibility; CITIC, China International Trust and Investment Service Corporation; MACHIMPEX, China National Machinery and Equipment Import and Export Corporation; CNNPC, China National Native Produce and Animal ByProducts Import and Export Corporation; CNTC, China National Tobacco Corporation; CT, Chia Tai Investment Company; CTIEC, China Tobacco Import and Export Corporation; FCTC, Framework Convention on Tobacco Control; FSU, former Soviet Union; GATT, General Agreement on Trade and Tariffs; GT, general trade; JV, joint venture; NBD, New Business Development; PM, Philip Morris; PRC, People's Republic of China; SEFK, State Express Filter King; SE555, State Express 555; SRBT, Sino-Russian Border Trade; STMA, State Tobacco Monopoly Administration; SUTL, Singapura United Trading Limited; TC, transnational tobacco company; WTO, World Trade Organization
} 


\section{METHODS}

The paper reviews documents only available, at the time of writing, on-site from the BAT Depository in Guildford, UK. Conditions of access to this collection are highly problematic, and precluded systematic searching of the entire collection. ${ }^{14-}$ ${ }^{16}$ The crude file level index available was iteratively searched in October 2003 using the keywords "China", "Chinese", "PRC" (People's Republic of China), "Sino*", "Peking/ Beijing", "Shanghai", "Guangdong/Canton", "Hong Kong", and "CNTC". This resulted in the retrieval of 226 files. In addition, China related regional documents found in files on the Asia-Pacific region of BAT were indexed. A total of 1538 documents were indexed in detail in a specially designed database to enable the construction of an historical narrative. Given the crude index at the Depository, documents on China located under file titles not containing the above keywords are necessarily excluded. Documents placed in the Minnesota Depository related to BAT (around one million pages) were manually searched page by page, given the lack of searchable index, in July and August 2003. Industry trade publications, newspaper articles, and academic journals were reviewed for information relevant to TTCs in China.

\section{RESULTS}

\section{An open door to a "difficult market"}

For the first 30 years of Communist rule (1950s to 1979), the Chinese market remained firmly closed. The "open door policy" announced by Deng Xiaoping in 1979 marked a radical policy shift, signalling a desire to integrate market economics with Chinese socialism. TTCs were among the first foreign businesses to explore this opportunity, acutely aware of the need to establish an early competitive advantage. However, initial enthusiasm soon gave way to the realisation that China remained a "difficult market" $t^{\prime 9}$ posing numerous challenges.

First, the complex bureaucracy proved an immediate barrier. Trade remained tightly controlled by a Ministry of Foreign Trade that owned a number of corporations solely responsible for trade in specific commodities. ${ }^{17}$ Until the early 1980s, trade in tobacco leaf and cigarettes was the responsibility of the China National Native Produce and Animal By-Products Import and Export Corporation (CNNPC). This structure was replicated at provincial level, where foreign companies needed to establish formal relationships with provincial CNNPC offices. Longstanding tensions between central and provincial government often made this awkward, as the provinces jealously guarded their authority over the local tobacco industry as a lucrative source of tax revenue. BAT's Group Advisor on Chinese Affairs JPHD Payne described the CNNPC as "a mammoth corporation... locked in a power struggle with several of its Provincial Branch Offices".

Second, central planning created volatility in leaf production and market instability. In 1980, a poor crop resulted in a severe domestic shortage, but the government's subsequent raising of the procurement price produced a substantial glut as domestic supply grew by $107 \%{ }^{18}$ Low grade cigarettes then flooded the market which, along with the limited availability of foreign exchange, prompted the government in 1982 both to reduce foreign imports by $36 \%$ annually and to press TTCs to lower their export prices. ${ }^{9}$ This led to efforts by TTCs to jointly resist the new policy:

BAT HK, in company with other Western manufacturers, feels that a further increase in the retail price in China is called for... BAT HK met with PMI [Philip Morris International] and RJR [RJ Reynolds] to discuss the former's proposal for the industry to halt further exports to the PRC, until such times as sensible pricing can be achieved. ${ }^{9}$

Third, the Chinese government was not offering foreign ownership and continued to restrict imports, keen only to secure technology and advice to improve manufacturing capacity and leaf growing. For BAT, such opportunities were not enticing:

Let us be under no illusion that the only reason for CNTC's overtures to BATCo (and other foreign manufacturers) is to persuade or coerce us into subsidising a) their leaf development schemes, b) their factory modernisation programmes, so they can rapidly upgrade their quality and compete with us in the export markets of the world...19

In this context, BAT cautiously focused on low risk activities that would bring direct benefits to the company. In 1979 BAT began conducting leaf trials in Yunnan province aiming to establish "either a possible alternative source for the world market or as an import substitute for the benefit of the Chinese". ${ }^{9}$ BAT subsidiaries also made "regular limited purchases" of Chinese grown tobacco leaf as gestures of goodwill. ${ }^{20}$

Second, BAT offered to sell new and reconditioned machinery to the Beijing Light Industry No. 1 Bureau (BLI), using the opportunity of a 1979 agreement to establish an exclusive relationship and prevent competitors gaining a similar foothold:

\section{During the Trial Period and any extension of cooperation between the parties, BLI and BAT shall not negotiate or conclude any similar agreement with any other tobacco manufacturer or any other Light Industry Bureau in the People's Republic of China respectively. ${ }^{21}$}

From September 1981, BAT publicised its expertise more widely as machinery suppliers, particularly when the Chinese government needed to convert its bumper crop to cigarettes. Brochures were sent to 28 factories in 13 provinces, and machinery was ultimately supplied to at least three factories. ${ }^{22}$ While it was unlikely to be financially lucrative, BAT saw such supplies "mainly as a means to gaining an entree to factories in the provinces, to strengthen our contacts there". ${ }^{\prime \prime}$

A third activity was licensed manufacturing of BAT brands. Under the 1979 agreement between BAT and BLI, manufacture was initially limited to local brands, though BAT envisaged expansion to premium brands (most notably State Express 555) if international production standards were attained. ${ }^{23}$ Relationships during this period were characterised by keenness from the Chinese and by BAT's concern to ensure that cooperation was not financially compromising. This was helped by BAT's exemption from customs on raw materials and other inputs and the payment of a $2 \%$ royalty on retail sales of SE555. ${ }^{24}$

BAT's competitors were actively pursuing joint ventures (JVs) during this period. By 1979 it was reported that PM had signed agreements for $10 \mathrm{JVs}$ with Chinese authorities. ${ }^{11}$ In 1981 RJ Reynolds became the first TTC to manufacture in China with an agreement with the Xiamen Cigarette Factory to produce Camel Filters to sell through foreign currency outlets, followed in 1986 with the jointly established brand (Jinqiao) for the domestic and export markets. ${ }^{25}{ }^{26}$ Similarly, in 1985 Gallaher International identified a "successful local manufacturing operation" as one of the "prime components of our business" in China. ${ }^{27}$ 
In contrast, BAT remained cautious regarding such relationships. A 1983 report by Payne on preliminary discussions regarding JVs in China identified existing guidelines as making it "difficult to identify positive profitsources". Establishing a fully owned subsidiary in China was also rejected as untried, with Payne advising not "to blaze this trail nor to regard that route as a viable alternative without further research". ${ }^{\prime}$ It was concluded that if the Chinese could not "in advance, demonstrate that their scheme would prove economically beneficial to BAT, no involvement is likely to ensue". ${ }^{19}$ Joint ventures by other companies, which the Chinese government hoped would earn much needed foreign currency, were dismissed as unsuccessful and mutually unsatisfactory:

The CNTC are dissatisfied because the 'exporting rules' are circumvented by brand owners selling to Hong Kong (who then re-sell back into the PRC) and the foreign manufacturer is frustrated because he does not have totally free access to the PRC domestic market. ${ }^{28}$

BAT was especially cautious about the prospects of local manufacture of its international brands, particularly SE555, ${ }^{27}$ and expressed ongoing protectiveness of its "crown jewels". ${ }^{29}$ The value accorded to SE555 demonstrates the continuing relevance of BAT's pre-revolutionary dominance in China:

BAT has received many requests from PRC organisations wishing to manufacture SE 555 under licence, as this is still the most prestigious and best remembered International brand. None of the proposals indicate any real return to BAT. Until the joint venture rules become more attractive to the foreign partner, and the necessary brand ownership safeguards are incorporated, licensing of SE 555 for local manufacture will not be contemplated. ${ }^{27}$

In 1986 BAT did sign a memorandum of understanding with the Hong Kong based Chia Tai Investment Company (CT) to explore a possible joint venture focusing initially on leaf processing with the later prospect of cigarette manufacture and sales. ${ }^{30}$ Yet its prospective partner apparently viewed BAT's position as overcautious, seeming to feel that "BAT should not be seeking cast-iron guarantees [of sufficient financial returns] either from PRC or from C- $\mathrm{T}^{\prime \prime}{ }^{31}$

Overall, the Chinese market was assessed by BAT as "highly unfavourable to western manufacturers". BAT felt its competitors had "launched into premature manufacture" of lower quality products, while BAT restricted itself to economically viable leaf growing and machinery. ${ }^{19}$ It took care to receive payment in hard currency, and satisfied itself with widening its "network of contacts". BAT's strategy was "to keep a profitable foot in the Chinese door without extensive or irrevocable commitment, so that, if and when conditions become favourable, BAT will have a profitable base from which to expand". ${ }^{27}$

\section{Use of "alternative export routes/customers" to "improve direct penetration"}

While BAT remained wary about expanding its legal presence in China, documents suggest that illegal imports rapidly increased from the early 1980s to dramatically exceed legal imports. Tighter quotas introduced under the newly formed China National Tobacco Corporation (CNTC) kept all legal imports restricted to 1400 million sticks in 1982. Yet BAT describes rapidly growing sales to China during this period. In 1987 sales to the Far East region reached four times the 1986 volume, attributed in large part to "expanded distribution and demand" in China. ${ }^{32}$ In November 1990, total monthly sales to China by BAT alone reached a record high of 2343.7 million sticks (28 128 million per year). ${ }^{33}$ By comparison, official figures for legal imports by all TTCs in 1990 was only 10551 million. ${ }^{34}$

One key supply route for contraband during this period was from Hong Kong to the Xiamen Special Economic Zone Trade Company Limited, located in the southeast province of Fujian. From Xiamen, stock was transported onwards to other regions of the country. This included what BAT called "Sino-Russian Border Trade" (SRBT) where sales figures cited for specific brands reveal the scale of illicit operations. In November 1986, total shipments were 56 million sticks per month. ${ }^{35}$ By January 1989, monthly sales of SEFK (State Express Filter King) alone reached 40 million sticks (480 million annually), while sales of Kent were expected to reach 180 million sticks per month (2160 million per year) ${ }^{36}$ The projected sale of SE555 for 1989 in China, which BAT deemed to offer no "real return" if manufactured locally under licence, ${ }^{27}$ was projected at 233 million sticks per month (2800 million per year). ${ }^{37}$ So successful was this trade that the potential impact of local production may have restricted enthusiasm for a more substantial legitimate presence. For example, it was noted that, in discussions on developing a joint venture, " $\mathrm{C}$-T appreciate that BAT may be apprehensive re effect on BAT HK's exports to PRC". ${ }^{30}$

The documents suggest an occasional lack of organisational cohesion and an inability to exert sufficient control over some distributors. For example, shipments from Hong Kong to Xiamen intended for the SRBT were found diverted to Bangladesh, Taiwan and elsewhere. ${ }^{38}$ In 1983 Payne expressed concern "at the leakage of cigarettes from the People's Republic of China (PRC) to other Far Eastern territories". "This "leakage" was addressed in meetings in August and September 1986, with concerns including the impact on the highly profitable operations of BAT distributor Singapura United Trading Limited (SUTL) (see Collin et al in this supplement). ${ }^{39}$ In meeting notes dated 22 September 1986, Ronayn Coburn (BAT Singapore) wrote:

\section{[I]t was yet again made clear to BATHK that the continued disruption to BATUKE [British American Tobacco United Kingdom Export]/SUTL interests in the key Bangladesh market resultant from massive leakage from Hong Kong was totally unacceptable. This situation, it was reiterated, was not only putting the BATUKE/SUTL operation and relationship at increasingly serious risk but also, in Group terms, placing in grave jeopardy a source of major financial contribution... \\ Under no circumstances will any further shipments of SEFK be made to Xiamen SEZ since BATUKE (RJMC) [Coburn] at least remains convinced that this customer, beyond all reasonable doubt, has been a principal, if not the sole, source of leakage in recent months. ${ }^{40}$}

Despite "leakage", there was only a brief halt to supplies and smuggling remained remarkably lucrative. From 19891993 BAT exports to China quadrupled, with only a small proportion (5.4\% in 1993 ) reportedly passing through legal channels. ${ }^{41}$ The "strength of the cross-border trade from Hong Kong into the semi-autonomous Southern provinces" 42 ensured BAT brands reached key urban markets and beyond.

By the early 1990s, however, BAT's reliance on contraband led to a growing sense of vulnerability, particularly as competitors pursued a legal presence in China. In 1991 Rothmans formed a joint venture in Shandong to produce three brands, ${ }^{21}{ }^{43}$ and in 1993 PM concluded a joint venture to manufacture Marlboro in Shanghai. The fear that this greater manufacturing presence by TTCs in China would lead to a 
crackdown on smuggling was identified as among the key threats to BAT's business plans:

Authorities' efforts to curb illegal imports will increase, although they will remain sporadic and inconsistent. However, access of exports from PAC RIM [Pacific Rim] countries will still be possible. ${ }^{44}$

Similarly, in a 1993 memorandum marked "SECRET" from Susan Osborne (Brand Manager SE555, BATCo) to Jimmi Rembiszeski (Marketing Director, BATCo), the PM joint venture was described as a threat to import dependent brands "555, Kent and Hilton" which "may suffer from [a] tightened policy". Osborne warned:

You will see from the attached that PM has confirmed an JV agreement to manufacture Marlboro in Shanghai (capacity unknown). Clearly this is consistent with their strategy to build legitamite [sic] domestic sales.

I believe that this action may have serious implications for our GT [general trade, a euphemism for cigarette smuggling ${ }^{39}$ ] business in China in the medium to longer term.

I address this to you in the context of 555

Issues/assumptions

1. The Beijing government is capable of controlling product flow

2. Given the profile the Chinese government is seeking as a world leader (for example, 2000 Olympics) it is unlikely that they will want to be perceived as the contraband capital of the globe

3. Once Marlboro is manufactured locally manufactured 555, Kent and Hilton, dependent on import may suffer from tightened policy

4. I am not aware of current BAT JV status in China via BAT China or the NBD in Windsor House

5. Certainly we would locally manufacture 555 as opposed to sacrifice the consumer franchise if exports become restricted (555 original heritage was locally made prior to 1948)..$^{45}$

Concerns about risks to contraband sales were supported by growing efforts by Hong Kong and Chinese authorities to investigate smuggling. In May 1991 it was reported by BAT HK that customs officials in Wenzhou "made a surprise move by burning up 400 cases of contraband foreign cigarettes". ${ }^{46}$ In 1994 the government confiscated 510000 cases of smuggled cigarettes, estimated to be a small fraction of the US\$1 billion in lost revenue annually. The CNTC estimated that $99 \%$ of foreign cigarettes sold in China in 1996 were contraband. ${ }^{47}$ In 1998 Premier Zhu Rongji and President Jiang Zemin began a long running anti-smuggling campaign, including investigating the suspected involvement of the People's Liberation Army in the illegal trade. ${ }^{12} 4849$ In Hong Kong, investigations under the Independent Commission Against Corruption led to the murder of a key witness, and a BAT Hong Kong executive was convicted of taking bribes in connection with cigarette smuggling. Reports indicate that BAT sales to a Hong Kong based network smuggling into China and Taiwan, and backed by the Triad (organised criminal group), totalled approximately US\$1.2 billion between 1987 and 1993. ${ }^{39}$

$\mathrm{BAT}^{\mathrm{s}} \mathrm{s}$ response to this riskier environment was " $[\mathrm{t}] \mathrm{o}$ improve overall availability, particularly direct supply in North and Central regions" to ensure that its brands would maintain a strong market presence in the face of growing competition. The company also stated that it would “investigate alternative export routes/customers that will improve direct penetration of UK brands in northern and central provinces" ${ }^{\prime \prime 50}$ given legal sale of imports were focused primarily in Beijing, Guangdong and Shanghai.

\section{"To gradually increase sales through CNTC so as to improve positive sales ratio over other channels"s1}

A second strategy by BAT was to seek a firmer legal footing in China. Expectations of China's potential economic stature were beginning to be realised. The economy grew by $8.2 \%$ per annum between 1978-95, ${ }^{52}$ outperforming the recession hit countries of North America and Western Europe. In 1986 the Chinese government submitted its membership application to the General Agreement on Tariffs and Trade (GATT), later the World Trade Organization (WTO), signalling its commitment to further expand foreign trade and investment. BAT expected membership to reduce barriers to market entry by TTCs.

BAT drew on its experience in other emerging markets. In 1991 it had formed the New Business Development unit (NBD) to develop new investment opportunities, ${ }^{13} 53$ particularly in the former monopoly markets of Eastern Europe and the Far East. ${ }^{54}$ In January 1993, BAT undertook a major company restructuring entitled "Project Rubicon", driven by concerns that NBD could not adequately deal with all the opportunities available at the time. ${ }^{55} 56$ It was felt that BAT's decentralised structure was inefficient, ${ }^{57}{ }^{58}$ and there was an urgency "to exploit the growing opportunities for its brands in world markets". ${ }^{59}$

In 1993 BAT formed a specific NBD Team for China "[t]o assist BAT Industries in the development of new investment opportunities". ${ }^{60}$ Strategies to be used, namely acquiring "best production capacity" and achieving "limited exclusive brand opportunities", had already been tried and tested in what BAT described as "it's first stage of NBD acquisitions" in Eastern Europe and the former Soviet Union. ${ }^{12}{ }^{61}$ In China, an immediate scaling up of company presence was planned, including opening four more area offices in 1993 "to maximise our focus on the China market". ${ }^{62}$

By the mid 1990s, BAT was actively pursuing closer cooperation with Chinese counterparts which it had previously been reluctant to engage. The company's aim was "To gradually increase sales through CNTC so as to improve positive sales ratio over other [illegal] channels. ${ }^{\prime 51}$ Despite a slower start, BAT aimed to overtake the competition via a "'first strike' mindset" to establish market leadership. ${ }^{63}$ This proactive strategy included a desire for agreements on licensing, contract manufacturing, profit sharing, marketing only joint ventures, strategic alliances and, most sought after of all, equity JV. ${ }^{59}$

On 22 February 1995 a letter of intent was signed with a number of provincial tobacco companies for leaf and manufacturing projects. The letter of intent was seen as a means to:

\section{- Develop and maintain first class relationship with STMA/ CNTC \\ - Enhance the corporate image of BAT as a credible and responsible multinational \\ - Build up BAT's capability to influence in the industry ${ }^{64}$}

For these purposes, BAT sought local partners that were politically influential, strategically important to the STMA/ CNTC, and willing to cooperate on a long term basis towards an equity JV. The establishment of "contract manufacturing", plus a marketing and sales joint venture, was intended to achieve several objectives including the establishment of a legal entity, side stepping CNTC's over-capacity problem and: 
- To increase sales volume through normal channel - To normalise and increase BAT's control on marketing activities $^{62}$

After prolonged negotiations, BAT signed an agreement in 1996 with the Guizhou Huang Guo Shu Group, the second largest provincial tobacco producer, ${ }^{65}$ to jointly develop a new lights brand. The agreement was heralded as a major competitive breakthrough, although the brand was not launched until May 2000. ${ }^{66}$ The agreement also fell short of the equity JV that was now BAT's "ultimate goal" ${ }^{67}$ BAT was pursuing an equity JV for key brands SE555 and Kent, in the form of localised manufacturing, and a permanent manufacturing and business base. ${ }^{62}$ Additionally, BAT wanted an agreement with the CNTC "which would allow control over marketing and distribution of our brands within the PRC". ${ }^{68}$ NBD China was charged with the task of establishing a full JV that would enable quality control, and competitive advantage via sales representatives on the ground. ${ }^{62}$ Through such an operation, BAT sought "[t]o obtain a $15 \%$ share of the Greater China market by 2015", representing 250 billion sticks of which 168 billion would be BAT brands and 82 billion jointly developed brands. ${ }^{66}$

As negotiations progressed for China's accession to the WTO, including reduced tariffs on imported cigarettes, competition among TTCs to gain market entry intensified. Yet, according to industry reports, progress by all companies remained slow. Despite concerted efforts to woo Chinese authorities, and various agreements were reached after prolonged negotiations, an equity JV remained elusive. For example, in 2001, BAT chairman Martin Broughton's announcement that the Chinese government had granted approval for the signing of a joint venture was met with the comment by an STMA official that "the Chinese tobacco industry is not open to foreign investment". ${ }^{69}$ When the company again announced in July 2004 that it would become the first foreign company to manufacture cigarettes in China, ${ }^{70}$ STMA officials again quickly denied approval had been given. ${ }^{71}$ With massive oversupply of tobacco domestically under central planning, the government was not keen to encourage increased imports. ${ }^{72}$

\section{Increasing advertising "where restrictions are not fully enforced"}

As well as the active pursuit of a joint venture, BAT commissioned detailed market research about the diverse Chinese market. Initial research confirmed BAT as the clear market leader among foreign imports led by SE555, although official imports comprised under $1 \%$ of the total Chinese market in the early 1990s. ${ }^{33}$ The identified strategy was "to further grow SE555's dominant share from $13.6 \%$ in the imported segment in the duty paid and duty free markets" based on the brand's "intrinsic exclusivity and prestige". Premium local brands such as Panda, Zhonghua, Ashima, Red Pagoda, and Yun Yan were acknowledged, but the longer term threats were identified as Marlboro and Rothman's Dunhill brands:

SE555 has no available imported equivalent in terms of heritage, status, or prestige. However, Marlboro has historically attempted (and so far failed) to embark upon a pricing strategy of achieving retail pricing parity with SEFK which could threaten the premium pricing, and consequently status values of SEFK.

With the strong imagery of Marlboro, as well as the strong status and gift giving qualities [supporting] more widespread consumer penetration, Marlboro represents the greatest immediate threat to SE555. ${ }^{73}$
At the lower end of the market, Hilton was identified as BAT's "value for money" brand intended to be "the 'starter' or 'staging' brand" for the all important Chinese mass market where most consumers were then placed. It was hoped that, as the country became more prosperous, consumers would "trade up from local to import brands, often to higher priced imports". ${ }^{74}$ Hence, Hilton would serve as a lower price alternative to SE555. ${ }^{75}$

The documents reflect an urgency to increase spending on marketing to match competitors despite the introduction of the Control of Tobacco Products law in 1992 which, inter alia, banned advertising in the print and broadcast media. ${ }^{76} \mathrm{PM}$ was reportedly spending "twice as much as BAT on communications", with " $90 \%$ of total expenditure" on marketing on the European Community and Far East, the spending gap having grown particularly pronounced in support of international brands. ${ }^{77}$ From 1993-94 BAT increased communication spending in China by $43 \%{ }^{78}$ While advertising restrictions were not fully enforced in some provinces, BAT anticipated that these would "succumb to Central Government's pressure to enforce the advertising ban". ${ }^{74}$ The BAT China company plan therefore proposed substantial marketing activities to exploit this window of opportunity:

\section{- To maximise the opportunity to increase communication spend behind major media, especially TV, in strategic regions to build brand awareness of international brands. - To actively secure quality outdoor signages in major cities for long term in anticipation of clamp down on major media for cigarette advertising. \\ - To work with other tobacco companies to lobby the Central Government in relaxing restriction. ${ }^{79}$}

A key objective was to establish and then increase advertising in key markets, notably Beijing, Shanghai, and Guangzhou. In 1992, BAT's overall marketing strategy targeted advertising agencies "that are well established in China, that provide a national service, are of international reputation, and are acceptable to IBM [International Brand Management] unit". ${ }^{80}$ The UK based advertising firm BSB was identified to lead BAT's scaling up efforts, with a strong emphasis on developing local contacts.

The best way of identifying media opportunities, achieving planned media buys and conducting initial negotiations is through local persons who are well connected to decisionmaking authorities in their own locales. The idea of doing business with one's own kind is very important to the Chinese.

In this respect, it is recommended that a network of local contacts or representatives be set up by BSB within China, to the extent of at least having one contact in each priority province. ${ }^{81}$

BAT sought to circumvent the 1992 national advertising restrictions by exploiting regionality (with local attitudes to advertising being seen as a function of distance from Beijing and relative economic autonomy), the increasing need for foreign currency, and local subjectivity in interpreting "what extraordinary circumstances provide sufficient reason to be flexible and to relax prohibitions":

In this environment where the only constant is inconsistency, it is obviously that media planning for cigarette products in China must be flexible, media strategies must be clearly defined by region, and tactics for negotiations 
must be creative and cognizant of the sensitivities to the product. ${ }^{82}$

\section{Corporate social responsibility in practice: preserving marketing freedom, undermining health}

BAT has long sought public relations opportunities to invest in communities in ways that advance commercial and political objectives. In 1992, for example, HK\$300 000 was given to repair the Haizhou bridge in Guangzhou, an investment viewed as "the sort of gesture to which officialdom will be obligated, and (that) can benefit 555 and BAT more ways than advertising alone" ${ }^{\prime 83}$ Such opportunities have recently been more systematically pursued as BAT's broader strategy has increasingly emphasised its high profile "corporate social responsibility" (CSR) initiatives ${ }^{84}$ The CORA (Consumer and Regulatory Affairs) section of the Asia Pacific North Company Plan 2000-2002 set the broad objective across Hong Kong and China of becoming "known as a responsible company in a business seen to be controversial". ${ }^{85}$

Activities such as endowing a Chair of Marketing at a Shanghai business school, sponsoring the Beijing Orchestra, and financing a "youth smoking prevention" programme have been depicted by BAT executives as evidence of the company's contribution to sustainable development in China ${ }^{86}{ }^{87}$ In contrast, internally the regional plan highlights the role of such exercises in promoting "a positive reputation in order to improve our ability to shape the future business environment". ${ }^{80}$ Such apparent philanthropy is rather part of a broader strategy to prevent tighter marketing restrictions. ${ }^{88}$ CORA proposed a number of actions to "promote advertising and sponsorships as vital business activities" in China including: "Continue to lobby for marketing freedom", "Influence the drafting of the supplemental tobacco advertising laws", and "Lobby the Ministry of Public Health to reprioritise health issues. Hepatitis is the number l killer disease in China." The key performance measure for success in securing such a reorientation would be that " $(\mathrm{t})$ he liver disease prevention program is endorsed by and goodwill is generated among the Ministry of Public Health and senior government leaders" ${ }^{.3}$

The disregard for public health characteristic of such "corporate responsibility" is further illustrated by regional plans to "(p)ut ETS [environmental tobacco smoke] into its proper perspective", ${ }^{80}$ namely to create controversy around the scientific evidence linking second hand smoke and ill health. The plan emphasised promotion of "the concept of accommodation [such as smoking and non-smoking areas] to lobby for the delay of further restrictions on public smoking". Proposed activities in China included lobbying for the establishment of indoor air quality standards, the launch of a public education programme via the STMA website, and the continuation of a "PRC ETS research project". ${ }^{83}$ Such plans correspond with industry efforts elsewhere to undermine public debate on ETS. ${ }^{89}$

Critically, the plan also outlines proposals aimed at countering the WHO's Tobacco Free Initiative in China, with a strong emphasis on undermining negotiations for the Framework Convention on Tobacco Control (FCTC). BAT was the most vociferously critical among TTCs in its criticisms of the proposed convention, ${ }^{90}{ }^{91}$ and the Asian region assumed a critical role in its strategy to counter what BAT China's Ooi Wei-Ming (managing director) identified as "the spectre of global tobacco control". ${ }^{82}$ The strategies proposed to address the FCTC within China were:

(b) Form alliance with STMA in lobbying to defend the legitimacy and marketing freedom of the tobacco industry (c) Proactively publicise $\mathrm{WHO}^{\prime}$ s agenda and the progress on FCTC.

(d) Lobby the participation by officials of other ministries (including officials having financial, trade, taxation, environment, and agricultural portfolios in the FCTC Working Group and an inter-governmental negotiating body) to influence the drafting and be opposed in most part to the FCTC. ${ }^{83}$

The STMA is clearly identified as the key to achieving broader political influence over the FCTC, being repeatedly highlighted as the subject of proposed lobbying activities, with the intended outcome being that "STMA forms an alliance with BAT and adopts BAT company positions in its discussions and work with other ministries" ${ }^{83}$ An indication of the initial success of this strategy is provided by Brenda Chow's (director of public affairs, BAT China) reported claims that BAT "persuaded the monopoly to look at it from a national economic perspective", and secured the inclusion of STMA officials among China's negotiating team. ${ }^{92}$

\section{DISCUSSION}

BAT continues to portray its operations as born in, and "intrinsically linked to the social development" ${ }^{\prime 81}$ of, countries like China in which it established an early presence. This self serving portrayal may be disingenuous, but it highlights the distinctively global character of the company by comparison with other TTCs. ${ }^{93}$ BAT's performance and prospects in China remain shaped by this history. The company's competitive advantage is seen as residing in its long term presence, ${ }^{94}$ a major contributing factor to the current strength of SE555.95 In 2001 Martin Broughton cited this history as enabling the agreement to build a factory in Sichuan Province. ${ }^{96}$ In the announcement of a similar agreement in July 2004, with China Eastern Investments, to build an $£ 800$ million factory to produce 100 billion cigarettes annually, the Financial Times stated that "BAT is believed to have used its historic connections with China to facilitate the deal".${ }^{97}$ The difficulties following these agreements, and China's signing of the $\mathrm{FCTC}^{98}$ indicate that $\mathrm{BAT}^{\prime}$ 's recent progress has by no means gone unchecked. Nevertheless, despite initial reluctance, the company is today more ambitious in its China strategy than its competitors. ${ }^{99}$

This paper argues that BAT's initial strategy to re-enter China from the late 1970s was characterised by caution, in contrast with the active efforts by PM, RJR, and others. ${ }^{11}$ Frustrated by bureaucratic complexity, import quotas, and the terms for foreign investment set by the Chinese government, BAT limited itself to leaf development and equipment sales. Behind the scenes, however, it relied heavily on contraband to protect its lead position in the import market, and to penetrate new regions of the country. It was only when BAT began to feel vulnerable by its dependence on illegal imports that a firmer legal presence was sought. From the early 1990s, the company began to actively pursue a joint venture and increase marketing efforts.

These findings are pertinent for two reasons. First, the tactics used in China are remarkably similar to those used in the former Soviet Union (FSU) where a cautious stepwise approach, focusing initially on imports and later local manufacturing, was employed. ${ }^{12}{ }^{13}$ Here, the company was also more cautious than its major competitors in establishing legal imports and manufacturing, perhaps inappropriately so, and possibly missing major opportunities. Instead, permitting sales to build via smuggling was its key strategy. Interestingly, one of the key attractions of the FSU was its border with China, with BAT specifying that it would review its strategy for SE555 when more was known about the smuggling routes to China. Later, when seeking to reduce 


\section{What this paper adds}

China is the key new market for TCs but little is known so far about specific market entry strategies used over the past two decades. Previous analysis of China based on industry documents has drawn on documents available on-line which largely excludes documents related to BAT. This paper is the first detailed analysis of previously unseen documents only available on-site from BAT's Guildford Depository, focusing on the tactics used by the company to re-enter the Chinese market.

The paper demonstrates that BAT's actual strategy in China differs somewhat from its public stance. While the company has consistently sought to present itself as a preferred foreign investor to the Chinese government, including corporate social responsibility initiatives, in practice, it has engaged in dubious tactics to circumvent persistent barriers to market entry. BAT's efforts to use its historical dominance as leverage over other TCs in China is also shown.

dependence on contraband sales, the company effectively exploited weak local enforcement of advertising restrictions.

Second, these similarities with the Chinese context, in turn, can be used to inform the development of appropriate tobacco control measures. It is noteworthy that in China, where the transition to a market economy has been comparatively successful and the national government has so far effectively resisted local expansion of TTCs, BAT has still been able to build market presence. Admittedly, foreign brands remain a small albeit growing proportion of the total market. Yet it is clear that far better policing of imports (for example, through a tax marker system with appropriate monitoring and penalties) is needed. Restrictions on legal imports are meaningless where smuggling is so rife. Similarly, stricter local enforcement of advertising restrictions is needed in such emerging markets to prevent an undermining of national and international policy. More recently, BAT has sought to circumvent regulation through its sponsorship of the Chinese Grand Prix in September $2004^{100101}$ and its CSR initiatives. Comprehensive restrictions on marketing and advertising, in line with the FCTC, and effective enforcement by all levels of government, and by all governments, is the only effective way forward.

\section{ACKNOWLEDGEMENTS}

This research is supported by funding from the National Cancer Institute, US National Institutes of Health, Grant Number 1 ROl CA91021-01.

Documents cited in this paper not currently available on existing websites will be posted on the Tobacco Control Research page on the London School of Hygiene and Tropical Medicine website http:// www.lshtm.ac.uk/cgch/tobacco/index.html.

\section{Authors' affiliations}

K Lee, J Collin, Centre on Global Change and Health, London School of Hygiene \& Tropical Medicine, London, UK; kelley.lee@lshtm.ac.uk A B Gilmore, European Centre on Health of Societies in Transition, London School of Hygiene \& Tropical Medicine

Conflicts of interest: No competing interests

\section{REFERENCES}

1 Kluger R. Ashes to ashes. New York: Vintage Books, 1996.

2 Yang G, Fan L, Tan J, et al. Smoking in China, findings of the 1996 National Prevalence Survey. JAMA 1999;282:1247-53.

3 Liu RB. Step By Step, It will take time before foreign cigarette makers can reap the full benefits of China's WTO membership. Tobacco Reporter 2002;March:26-8.
4 World Health Organization. Smoking in China: a time bomb for the $21 \mathrm{st}$ century. Fact Sheet No. 177, August 1997. www.who.int/ffi.

5 Hu A. Towards coordinated growth. Tobacco Journal International 2002;5:100.

6 Cox H. The global cigarette. Origins and evolution of British American Tobacco 1990-1945. Oxford: Oxford University Press, 2000:149.

7 BAT China, Business Department, "History of BAT in China," 27 November 1995, Guildford Depository, Bates No. 50049097.

8 Cochran S. Big business in China, Sino-foreign rivalry in the cigarette industry, 1890-1930. Cambridge, Massachusetts: Harvard University Press, 1980.

9 Payne JPHD, "CHINA, The Past, The Present, The Future," Report Prepared for C. H. Stewart Lockhart, Chairman BATCo, 29 July 1983, Guildford Depository, Bates No. 301045266-92.

10 Fletcher R. Rothman's Regional Public Affairs Manager as quoted in Ibison D, "Rothman's Deal Opens Heavenly Gates," Windows Magazine (Hong Kong), 16 October 1992:4

11 O'Sullivan B, Chapman S. Eyes on the prize: transnational tobacco companies in China 1976-1997. Tobacco Control 2000;9:292-302.

12 Gilmore AB, McKee M. Moving East: how the transnational tobacco industry gained entry to the emerging markets of the former Soviet Union-part I: establishing cigarette imports. Tobacco Control 2004;13:143-50.

13 Gilmore AB, McKee M. Moving east: how the transnational tobacco companies gained entry to the emerging markets of the former Soviet Union. Part II: an overview of priorities and tactics used to establish a manufacturing presence. Tobacco Control 2004;13:151-60.

14 Lee K, Gilmore AB, Collin J. Research of the Guildford Depository: an untapped resource for tobacco control. Addiction 2004;99:394.

15 Collin J, Lee K, Gilmore AB. Unlocking the corporate documents of British American Tobacco: an invaluable global resource needs radically improved access. Lancet 2004;363:1746-7.

16 Muggli ME, LeGresley EM, Hurt RD. Big tobacco is watching: British American Tobacco's surveillance and information concealment at the Guildford depository. Lancet 2004;363:1812-19.

17 Lardy N. Integrating China into the global economy. Washington DC: Brookings Institution, 2002:30.

18 FAO. Issues in the global tobacco economy: selected case studies. Rome: Food and Agricultural Organization, 2003.

19 BAT. "Draft China Strategy," n.d., Guildford Depository, Bates No. 303665583-584.

20 Payne JPHD, "Co-ordination-Far East," Report to T. J. Lyon, BATCo, 7 March 1983, Guildford Depository, Bates No. 303665529-537.

21 BATCo. "Contract," 6 December 1979, Guildford Depository, Bates No. 301045232-41.

22 BAT China, Business Department, "History of BAT in China," 27 November 1995, Guildford Depository, Bates No. 500049098.

23 BATCo. "Consignment Contract For Cigarettes (Translated from original agreement written in Chinese)," 21 October 1981, Guildford Depository, Bates No. 301045253-57.

24 BATCo. "Contract For Processing Materials Supplied For State Express 555 King Size Filter Tipped ("555 Cigarettes") Contract No: 82NO1A," 1982, Guildford Depository, Bates No. 301045228-31.

25 BAT China. "Business Development, Competitor Activities," 1995, Guildford Depository, Bates No. 500049109-121.

26 Reynolds RJ. Press Release, 20 June 1983, Bates No. 502281393-395. URL: http://www.legacy.library.ucsf.edu/ [Accessed 8 June 2004].

27 Gallaher International. "China Market Plan 1985/86," 1985, Bates No. not provided. URL: http://www.legacy.library.ucsf.edu/ [Accessed 8 June 2004].

28 BATCO. "China Strategy," 2 December 1982, Guildford Depository, Bates No. 301045336.

29 Adams Paul N. "Note to Mr G Li, Re: China-LOI," 5 January 1995, Guildford Depository, Bates No. 500048826-827.

30 Wai, Pong. "Restricted, Comments On Memorandum Of Understanding Between Chia Tai And BAT," Hong Kong, 7 January 1986, Guildford Depository, Bates No. 301045331.

31 Payne JPHD, BATCo. "File Note, Meeting held in Millbank with Chia-Tai to discuss possibilities for co-operating with C-T in the PRC," 14 January 1986, Guildford Depository, Bates No. 301045298.

32 BATUS. "Tobacco Group First Half 1987 Quarterly Profit Review (BATUS Board Meeting)," 1987, Guildford Depository, Bates No. 201759194.

33 BATCO. "General Manager's Review," November 1990, Guildford Depository, Bates No. 304002080-82.

34 Shafey O, Dolwick S, Guindon GE. In: Tobacco control country profiles, 2nd ed. Atlanta, Georgia: American Cancer Society, WHO and International Union Against Cancer, 2003.

35 Aitken J. "re Sino-Russian border supply," Telex, 19 November 1986, Guildford Depository, Bates No. 301634284

36 Wai, Pong. "General Managers Monthly Review. January 1989 China," 2 February 1989, Guildford Depository, Bates No. 301634045-48.

37 Scott, Mike. Letter to J.M. Aitken, 16 August 1989, Guildford Depository, Bates No. 301633986

38 Ronayne Coburn, Letter to Brian Brockman, 25 September 1986, Guildford Depository, Bates No. 301634320.

39 Collin J, Le Gresley E, MacKenzie R, et al. Complicity in contraband: British American Tobacco and cigarette smuggling in Asia. Tobacco Control 2004;13(suppl II):ii104-11.

40 Coburn, Ronayn. "File Note Hong Kong Meeting-22nd September 1986," 22 September 1986, Guildford Depository, Bates No. 301634322-24.

41 International Consortium of Investigative Journalists. Tobacco companies linked to criminal organizations in cigarette smuggling: China. http:// 
www.publicintegrity.org/dtaweb/report.asp?ReportID = 127\&L1 = $10 \& \mathrm{~L} 2=10 \& \mathrm{~L} 3=0 \& \mathrm{~L} 4=0 \& \mathrm{LL}=0$.

42 BATCo. "China Strategy," 2 December 1985, Guildford Depository, Bates No. 301045333

43 PM. "Distribution: January 1994 Competitor Review," 8 February 1994, Bates No. 2023009524-540. URL: http://www.legacy.library.ucsf.edu/ [Accessed 8 June 2004].

44 BAT. "China Briefing Document", 1992, Guildford Depository, Bates No. 301591522-606.

45 BATCo. "PM JV China Secret," Memo from Susan Osborne to Jimmi Rembiszewski, 13 August 1993, Guildford Depository, Bates No. 500199483-484.

46 BAT HK. "General Manager's Review," May 1991, Guildford Depository, Bates No. 201823860.

47 Anon. China: BAT plots China offensive. Guardian, 3 January 1996.

48 Cook R. Smugglers on the run. Sunday Morning Post (Hong Kong) Postmagazine 13 September 1998:10-15.

49 Anon. China says war on smuggling boosting trade balance with Hong Kong Inside China, 2 February 2000.

50 BAT. "China-SE555 1993-1997," 1993, Guildford Depository, Bates No. 500199391-403.

51 BATCO. "BAT China Company Plan 1993-1997," 1992, Guildford Depository, Bates No. 500323401.

52 Lardy N. Integrating China into the global economy. Washington DC: Brookings Institution, 2002:11-12.

53 BATCo. "Eastern Europe/USSR," 2 October 1991, Guildford Depository, Bates No 201789795-797.

54 Barton H. "NBD Strategy," 18 November 1992, Guildford Depository, BAT, Bates No. 201789654-658.

55 Barton H, BAT. "New Business Development Strategy," 17 May 1993, Guildford Depository, BAT, Bates No. 203469331-335.

56 Barton H, "Tobacco Strategy Group," 11 December 1992, Guildford Depository, BAT, Bates No, 203469531-533.

57 Brookes N. "Note To The Chief Executive's Committee, Organisation Of New Business Development," 1 September 1993, Guildford Depository, BAT, Bates No. 203469314-324.

58 Barton H. "Draft B.A.T. Industries Tobacco Strategy (Tobacco Strategy Group, 19th May 1993, Agenda item 7)," 12 May 1993, Guildford Depository, BAT, Bates No. 203469465-485.

59 BATCo. "1992 Business Review," 1992, Guildford Depository, Bates No. 203481215-248.

60 BATCo. "Secret BATCo Performance Objectives - 1993," 23 February 1993, Guildford Depository, Bates No. 503952868

61 BATCo. "1996-2000 Planning Cycle," Guildford Depository, Bates No. 503909740-755.

62 BATCo. "Asia Pacific, BATCo performance objectives 1993," 14 January 1994, Guildford Depository, Bates No. 503952870.

63 BAT China. "Trade Marketing," n.d., Guildford Depository, Bates No. 500049019

64 BAT China. "History of BAT in China," 27 November 1995, Guildford Depository, Bates No. 500049103-106.

65 China Statistical Yearbook, p. 402 as cited in MacKay J. "Not for all the tea in China..." Tobacco Control 1999;8:224.

66 "A Milestone Achievement in Huang Guo Shu and BAT Cooperation," Tobacco China, 6 June 2000.

67 BAT China. "Trade Marketing," n.d., Guildford Depository, Bates No. 500049019

68 *BAT China Ltd. "Company Brief to JV Advisers," 13 September 1995, Guildford Depository, Bates 500048949.

69 Jia HP. International tobacco firms seek to light up China market. China Daily, 29 May 2001.

70 Woolner A. BAT to build first Western tobacco factory in China. Independent (UK), 17 July 2004.

71 UK Chinese Embassy. "Regulator Denies Approving Tobacco Joint Venture," Statement by Chinese Embassy to the U.K., 22 July 2004. http:// www.chinese-embassy.org.uk/eng/xw/ $1143744 . h t m$.

72 Anon. China, No more joint ventures. Tobacco Journal International 2002;5:8.

73 BATCo. "China Briefing Document, SE555 China," 1992, Guildford Depository, Bates No. 301591549.
74 BAT. "China Briefing Document", 1992, Guildford Depository, Bates No. 301591522-606.

75 BATCo. "Secret, BATCO Performance Objectives-1993," 23 February 1993, Guildford Depository, Bates No. 503952880

76 People's Republic of China, Law on the Exclusive Sale of Tobacco, Article 19. http://ffi.wpro.who.int/global_leg_type_1.asp?nation_ code $=45 \&$ cat_id $=3$.

77 Philip Morris. "Philip Morris Competitor Report," n.d., Bates No. 6991 15794-816. http://www.legacy.library.ucsf.edu/ [Accessed 8 June 2004].

78 Magnacca M. "Critique-1994 BAT China Plan," Memo to Susan Osborne, 9 August 1993, Guildford Depository, Bates. No. 500199480-82.

79 BATCO. "BAT China Company Plan 1993-1997," 1992, Guildford Depository, Bates No. 500323402.

80 BATCo. "China Briefing Document, UK Brand Strategies-China," 1992, Guildford Depository, Bates No. 301591546.

81 BATCo. "China Briefing Document, Advertising Agencies," 1992, Guildford Depository, Bates No. 301591556.

82 BATCo. "China Briefing Document, Media Strategy," 1992, Guildford Depository, Bates No. 301591559.

83 BATCo. "China Briefing Document, Media Strategy," 1992, Guildford Depository, Bates No. 301591561 .

84 Collin J, Gilmore AB. Corporate (anti)social (ir)responsibility: Transnational tobacco companies and the attempted subversion of global health policy. Global Social Policy 2002;2:354-60.

85 BAT, CORA. "Asia Pacific North, 2000-2002 Company Plan," Extract, n.d., Minnesota Tobacco Document Depository, Bates No. 325024794-796.

86 Broughton M. Sustainable development: what can business achieve? Speech to the Business Advisory Mission for Yunnan Province, Western China, Kunming City. 17 June 2000. www.bat.com [Accessed 10 July 2004].

87 Ooi Wei-Ming. Keynote speech: World Tobacco Symposium \&Trade Fair, Hong Kong, 27 October 1999. www.bat.com [Accessed 10 July 2004].

88 BAT, CORA Hong Kong and China. "Asia Pacific North. 2000-2002 Company Plan," n.d., Minnesota Tobacco Document Depository, Bates No. 325024797-806.

89 Ong E, Glantz S. Tobacco industry efforts subverting International Agency for Research on Cancer's second-hand smoke study. Lancet 2000;355: 1253-59.

90 Broughton M. 'Doing Business in a Borderless World', Speech, International Chamber of Commerce, $33^{\text {rd }}$ World Congress, Budapest, Hungary, 5 May 2000. www.bat.com [Accessed 10 July 2004].

91 Collin J, Lee K, Bissell K. Negotiating the Framework Convention on Tobacco Control: the politics of global health governance. In: Wilkinson R, Murphy C, eds. Global governance: a reader. London: Routledge, 2004.

92 Loewenberg S. Tobacco Lights Into WHO: Industry Pushes to Influence October Treaty Debate Over Global Curbs on Cigarettes, Legal Times, 11 September 2000 http://lists.essential.org/pipermail/intl-tobacco/2000q3/ 000276.html [Accessed 9 July 2004].

93 Fisher B. The power of regionalism. Tobacco Reporter. June 2001. www.tobaccoreporter.com/backissues/June2001/story4.asp [Accessed 9 July 2004].

94 Tobacco Journal International. Packing for the Far East. December 2002 http://www.tobaccojournal.com/show_artikel.php3?id = 2877\&banner = rentsch [Accessed 10 July 2004].

95 Monteiro de Castro A. Obtaining volume leadership, Interviewed. Tobacco Journal International, 2004 (4) http://www.tobaccojournal.com/ show_artikel.php3?id=3865 [Accessed 10 July 2004].

96 Broughton M. Speech at the BAT Annual General Meeting, 2 May 2001. www.bat.com [Accessed 3 Jul 2004].

97 Anon. Financial Times, 17 July 2004

98 World Health Organization. Updated status of the WHO Framework Convention on Tobacco Control. http://www.who.int/tobacco/areas/ framework/signing_ceremony/countrylist/en/ [Accessed 11 Jul 2004].

99 Anon. Tobacco sector opportunities. Tobacco Journal International Special, March 2004. http://www.tobaccojournal.com/ show_artikel.php3?id = 3709\&banner $=$ kurz2 [Accessed $10 \mathrm{Jul} 2004$ ]

100 Carlyle J, Collin J, Muggli ME, et al. British American Tobacco and Formula One motor racing. BMJ 2004;329:104-6.

101 Collin J, Muggli ME, Carlyle J, et al. Race to the death: British American Tobacco and the Chinese Grand Prix. Lancet 2004;364:1107-8. 